\title{
Seslenme Sözleri ve Genel Türkçe Sözlüklerdeki Görünümü*
}

\author{
Fatih DOĞRU**
}

Seslenme Sözleri ve Genel Türkçe Sözlüklerdeki Görünümü

Özet

Biri ya da birilerine yönelik olarak söz söylenirken o kimselerin kimi özelliklerine bağlı olarak bazı sözlerle seslenilir. Bu sözler; sözün yöneltildiği kişinin kendi adı, soyadı, lakabı veya zamirler olabileceği gibi bunun yanında çoğu zaman o kişinin adının yerine geçen; konuşucunun çeşitli duygularını yansıtma özelliği bulunan ve sözün yöneltildiği kişinin bir takım ayırıı özelliklerini yansıtacak şekilde sözlüksel anlam taşıyan sözlerdir. Bir dilin en sık kullanılan ögelerinden biri olan seslenme sözlerinin sözlüklerde ne şekilde tanımlandığı da kuşkusuz sözlük kullanıcıları için son derece önemli bir husustur. Bu bildiride hangi sözlerin seslenme sözü olarak değerlendirilmesi gerektiği konusuna açıklık getirilmeye çalışılacak; hangi yollarla oluşturuldukları tespit edilecek; kavramsal yönden hangi alt başlıklara ayrılabilecekleri ile ilgili öneriler getirilecek ve genel Türkçe sözlüklerdeki durum ortaya konmaya çalışılacaktır.

Anahtar Kelimeler: Seslenme Sözleri, Hitap, Ünlemler, Genel Türkçe Sözlükler
Addressing Words and Their Appearance in General Turkish Dictionaries

Abstract

While we call out to somebody we use some words related to their features. These words maybe names, surnames, nicknames and pronouns about the person addressed or these words may have some lexems which reflect distinctive features of the person addressed different feelings of the speaker. It is an important case for dictionary users, how to address words which are a frequent element in general vocabulary of a language defined in dictionaries. In this paper, we will try to clarify which words are addressing words; we will determine how they are formed and we will offer suggestions about which conceptional titles can be given for these words. We will discuss how we can arrange lexems in general Turkish dictionaries.

Key Words: Addressing Words, Address, Interjection, General Turkish Dictionaries

\section{Giriş}

İnsanlar dili kullanırken pek çok farklı amaç veya sebeple, farklı şekillerde birilerine / bir şeylere seslenirler. Bu seslenmeler; çağırma, uyarma, dikkat çekme, harekete geçirme, samimiyet / resmiyet gösterme, statü gösterme, onurlandırma, iletişimi kontrol etme, iletişimde olduğunu gösterme, çeşitli duyguları yansıtma (heyecan, sevinç, sevgi, saygı, nefret, korku, üzüntü, kızgınlık vb. gösterme), hakaret etme, küçük düşürme / aşağılama, alay etme, sitem etme, yardım isteme, azarlama,

\footnotetext{
* Bu çalışma 3-4 Kasım 2015'te gerçekleştirilen II. Uluslararası Sözlük Bilimi Sempozyumu'nda sözlü olarak sunulan aynı başlıklı bildirinin genişletilmiş şeklidir.

** Dr. Fatih DOĞRU, Eskişehir Osmangazi Üniversitesi, Türk Dili ve Edebiyatı Bölümü, fdogru@ogu.edu.tr, ORCID ID orcid.org / 0000-0002-1801-9725
} 
dua etme / yalvarma, tehdit etme vb. çeşitli amaç ya da sebeplerle içinde bulunulan kültür, cinsiyet, yaş, yakınlık / samimiyet, seslenen ve seslenilenin türü gibi değişkenlere bağlı olarak farklı şekillerde gerçekleşir. Bu şekilde birilerine ya da bir şeylere, onların bir takım özelliklerine göre yöneltilerek söylenen veya yazılan sözler, seslenme sözleridir.

Verici ile alıcı, hatip ile muhâtap arasında iletişimin sağlanabilmesi için bir duruma (situation) ihtiyaç vardır. Seslenmeler (hitaplar) / seslenme grupları (hitap grupları), söz konusu iletişimin gerçekleşmesinde "uyaran / uyarıcı / dikkat çekici" görevini üstlenirler. Yani verici, alıııya mesajı sözlü veya yazılı olarak iletirken önce ona seslenir / hitap eder ve onu bu seslenmeler vasıtasıyla iletişim ortamına çekerek mesajını iletir / bilgiyi aktarır (Alyılmaz, 2011: 646).

Kime veya neye seslenildiğini bildiren söz veya söz birleşmesi, seslenme öbeğini oluşturur. Kişinin özel adı olan sözler, akrabalık ve kavim adları, kişinin toplumdaki işini, mevkiini bildiren sözler, ilişki bildiren sözler, seslenme sözleri olarak kullanılabilir. Ayrıca çeşitli hayvan adları ve takma adlar, cansız eşyaların adları, coğrafi adlar, seslenme görevi üstlenebilir (Karaağaç, 2013: 695). Korkmaz (2010: 186) seslenme ünlemini; çağırmaya, haber vermeye ve cümledeki seslenmeyi güçlendirmeye yarayan ünlemler şeklinde tanımlarken; Delice (2012: 178) muhatabın dikkatini çekmek için kullanılan her sözcük seslenme ünlemidir ve özel isimlerin tamamı seslenme amacıyla kullanılınca ünlem edatı olur der. Seslenme fonksiyonu (appelative function) da sözün muhatabı uyarmak, ona kendi adının dışında bir kelime ile seslenmek için kullanııması fonksiyonu (Akşehirli, 2004: 38) olarak tanımlanmıştır.

\section{Türkçede Seslenme Sözleri}

\subsection{Türkçenin Genel Söz Varlığı İçinde Seslenme Sözleri}

Seslenme sözlerine Türkçenin genel söz varlığı içinde "kalıp sözler (ilişki sözleri)" başlığı altında yer verilir. Bu bağlamda seslenme sözleri "insanlara hitap etmek için kullanılan kalıp sözler" ve "hayvanlara hitap etmek için kullanılan kalıp sözler" olarak ikiye ayrılmıştır (Bulut, 2012: 54). "Insanın kendi kendine hitap etmek için kullandığı kalıp sözler”, "Tanrıya hitap etmek için kullanılan kalıp sözler", "doğadaki başka unsurlara hitap etmek için kullanılan kalıp sözler" de bunlara ilave edilebilir. Gencay (2012: 88-99) seslenme sözlerini "günlük hayatta kullanılan diğer kalıp sözler" başlığı altında vermiş ve kendi içinde "sevgiyi belirten sözler", "birini onurlandırmak için kullanılan sözler", "güzelliği yansıtan sözler", "kızgınlığı ve beğenmeme durumunu ifade eden sözler" şeklinde gruplandırmıştır. Şen (2008: 628) ise "ön yargı bildirmeyen seslenme amaçlı hitaplar", "olumlu ön yargı bildiren hitaplar" ve "olumsuz ön yargı bildiren hitaplar" şeklinde seslenmeleri üçe ayırıp bunları da seslenmelerin yönü doğrultusunda alt gruplarda ele almıştır. Seslenme sözleri Eski Türkçe döneminden bu yana Türkçenin söz varlığı içerisinde önemli bir yer tutmaktadır. Alyılmaz (1994: 82-83; 252-253) Orhun Yazıtları'nda, Alyılmaz (2015b) Dede Korkut Kitabı'nda, Demirbaş (2017) Türkiye Türkçesi Ağızlarında seslenme sözlerinin kullanılışı hakkında bilgi vermektedir. 


\subsection{Seslenme Sözlerinin Aldığı Ekler}

Türkçede seslenme sözlerinin oluşmasında bazı eklerin kullanıldığı görülmektedir. Korkmaz (2011: 39), unvan ve hitap olarak kullanılan 1. kişi iyelik eki almış bazı kelimelerde bu eklerin artık kendilerinin o kelimeler içindeki ilk görevini kaybetmiş olup sevgi ve hitap nüansları sağlayacak şekilde kaynaşmaya uğradığını belirtmektedir. Seslenişlerin (vokatif) Rus dilinde olduğu gibi Türk dillerinde de sesin gücü, uzunluğu, yüksekliğinin değişimine, hitap sözcüğüyle bir sonraki sözcük arasındaki duraksamanın uzunluğuna göre ve özel vokatif tonlamalar ile sözcükler aracılığıyla belirtilmekte olduğu ve bununla birlikte bazı Türk dillerindeki birtakım hitaplarda, sadece söz konusu grubun göstergeleri olarak ortaya çıkan vokatif biçimlerinin eklerini ayırmanın mümkün olduğunu aktaran Yoldaşev (2012: 441) bu ekler için çeşitli Türk dillerinden -a(v), -(a,ı)y eklerini, 1., 2. ve 3. teklik kişi iyelik eklerini, sevgi anlamı veren küçültme eklerini ve bunların 1. teklik kişi iyelik ekleriyle birleşmiş şekillerini örnek olarak verir (Yoldaşev, 2012: 441-445).

\subsection{Sözcük Türü Olarak Seslenme Sözleri}

Sözcük türü olarak seslenme sözleri "ünlemler" başlığı altında ele alınmaktadır. Ünlemler ise kimi çalışmalarda (Ergin, 2002: 313; Hacıeminoğlu, 1984: 293; Karaağaç, 2012: 437; Delice, 2012: 172) edat başlığı altında verilirken kimi çalışmalarda (Emre, 1945: 553; Kononov, 1956: 275; Atabay vd: 2003: 155; Banguoğlu, 2007: 396; Gencan, 2007: 533; Demirci, 2015: 145) müstakil bir sözcük türü olarak yer alır. Hacıeminoğlu (1984: 284) seslenme sözlerini ünlemlerden ayırarak "çağırmahitap edatları" başlığı altında verir.

Bunlar isimlerden veya unvanlardan önce gelerek hitap hareketini bilhassa belirtmekten başka hiçbir mânâları olmayan sözlerdir. Bir kısmı taklidi kelimelerdir, bir kısmı ise kalıplaşmış diğer gramer unsurlarıdır. Bu sebeple menşelerini tesbit etmek güçtür. Kullanılış bakımından da öbür edatlardan farklıdırlar. Daha çok konuşma dilinde veya senli-benli samimi bir eda taşıyan şarkı, türkü, hikaye ve şiirlerde rastlanır (Hacleminoğlu, 1984: 284).

Ergin (2002: 313-314), seslenme sözlerini edatlar başlığı altında verdiği ünlem edatları başlığı altında inceler. Seslenme edatlarının hitap edatları olduğunu, hiçbir ifadeleri olmadığını ve sadece hitap ve seslenme vasıtaları olduğunu söyler. Seslenme edatları hitap bildiren sözler (Karaağaç, 2009: 168) olarak kabul edilmektedir ve seslenmeler ünlem edatı kullanılarak veya kullanılmadan yapılabilir (Karaağaç, 2013: 695). Zülfikar (2011: 607), bu sözlerin bir kelime grubu olarak tayin edilmeyip sadece edatlar içinde zikredilmesini doğru bulmadığını ifade eder.

\subsection{Cümle Ögesi Olarak Seslenme Sözleri}

Seslenme sözleri cümle ögesi olarak da "cümle dışı unsur" başlığında ele alınırlar (Karahan, 1995: 59; Ergin, 2002: 376; Karaağaç. 2012: 512; Özkan ve Sevinçli, 2013: 101 ve 154). Bazı araştırmacılar ise "bağımsız tümleç" (Özmen, 1995: 224; Özmen, 2013: 48), "cümle ögesi olmayan yardımcı kelimeler" (Mehmedoğlu, 2002: 125-126), "dolaylı tamlayıcı" (Üstüner, 1998: 28-29), "ünlem tümleci" (Delice, 2007: 162), "seslenmeli özne" (Dizdaroğlu, 1976: 119), "seslenmeli tüm- 
Fatih DOĞRU

leç" (Hatipoğlu, 1972: 135) terimlerini ve cümle dışı unsur terimi yerine kullanılabilecek veya cümle ögesi olarak değerlendirilebilecek başka bazı terimleri önererek (Dinar, 2014: 71-77) seslenme sözlerini cümlenin ögeleri kapsamında önerdikleri bu başlıklar altında değerlendirmişlerdir. Verici ile alıı, hatip ile muhatap arasında iletişimin sağlanmasında önemli rol oynayan cümle ögesi için seslenme tümleci, seslenmeli tümleç, ünlem tümleci, seslenmeli özne, seslenmeler, seslenme grupları, seslenme blokları, hitaplar, hitap blokları, hitap grupları... terimleri kullanılmaktadır (Alyılmaz, 2015a: 36). Seslenmeler cümle içinde farklı sebeplerle (kuvvetlendirme, vurgu, vezin, kafiye, redif, ritm, uyum, melodi...) diğer cümle ögeleriyle yer / sıra değiştirebilir; cümlenin içinde veya sonunda bulunabilir (Alyılmaz, 2015a: 38).

\subsection{Söz Öbeği Olarak Seslenme Sözleri}

Seslenmeler / seslenme grupları vericinin ve alıcının durumlarına, birbirleriyle olan münasebetlerine ve mesajın niteliğine uygun olarak seslenme ünlemleriyle birlikte kullanılırlar. Seslenmeleri / seslenme gruplarını kuvvetlendirmek, pekiştirmek ve vurgulamak amacıyla kimi zaman işaretli, kimi zaman da işaretsiz (nonmarque $(\varnothing)$ ) olarak kullanılan ünlemler, gerçekte görevli dil ögeleri olmalarına rağmen, seslenmelerle / seslenme gruplarıyla adeta belirten belirtilen / tamlayan tamlanan ilişkisi kurarlar (Alyılmaz, 2011: 646). Seslenme ünlemleri, tek başına kullanılıp cümleyi doğrudan tamamlarsa asıl sözcüktür ve ünlem tümlecini oluşturur ancak bir ismin uydusu olarak ünlem edatı öbeğinin birinci bileşeni olursa ünlem edatı öbeğini oluşturur (Delice, 2012: 178). Grubu oluşturan ögeler araya herhangi bir ek almazlar (Özkan ve Sevinçli, 2013: 99).

\subsection{Anlamsal Özellikleri Bakımından Seslenme Sözleri}

Anlamsal olarak seslenme sözleri, temel anlamı seslenme olanlar (be, hey, hu vb.) ve yan anlam olarak seslenme anlamı kazananlar (ahbap, amca, dayı vb.) şeklinde ikiye ayrılabilir. Temel anlamı seslenme olan sözlerin dillerin doğuşu ile ilgili teorilere kaynaklık ettikleri (Akalın, 2011: 588) de ileri sürülmektedir. Bunlar daha çok çeşitli duygular karşısında çıkarılan seslerin sözcüklere dönüşmesiyle oluşmuştur denilebilir. Yan anlam olarak seslenme anlamı kazanan sözcükler ise kişi adları / soyadları, lakaplar, akrabalık adları, meslekle ilgili adlar, unvanlar, çeşitli özellikleri bakımından benzetme yoluyla oluşturulan adlar, hayvan adları, nesne adları, ilahi özellikli adlar, kişiler arası ortak yanları yansıtan adlar, zamirler ile vurgu ve tonlama yoluyla seslenme özelliği kazandırımış her türlü addan oluşabilir.

\subsection{Edimsel Özellikleri Bakımından Seslenme Sözleri}

Seslenme sözleri edimsel olarak dilde kibarlık ve kabalıkla yakından ilişkilidir. Dilbilim araştırmacıları tarafından çeşitli kibarlık / kabalık ilkeleri öne sürülmüştür. Lakoff (1975) "açık ol, kibar ol, resmiyet (mesafeli davran), saygı (seçenek tanı), dostluk / samimiyet (duygudaşlık ve dostluk göster)" ilkelerini; Leech (1983) "nezaket, cömertlik, övgü, tevazu, uyuşum, duygudaşlık" ilkelerini; Brown ve Levinson (1987) "yüz (olumlu yüz ve olumsuz yüz)” kavramına dayalı ilkeleri ortaya koymuşlardır (Doğru, 2014: 656). Seslenme sözlerine bu ilkeler ışı̆ı̆nda da yaklaşılabilir. Nezaket anlamı Türkçede genel olarak seslenmeler aracılı̆ııyla, ara söz ve ara cümlelerle, özne-yüklem uygunlu- 
ğu yoluyla ifade edilir (İmamova, 2010: 1). Türkiye Türkçesinde "bey, hanım, bay, bayan, efendi, beyefendi, hanımefendi" gibi seslenme ve hitap kelimeleri, "amca, teyze, beybaba, abla, kardeş, hemşire, dede, nine, evlat, yavru, oğul, kız" gibi akrabalık ilişkilerine ait sözlerden oluşan seslenme sözleri, "öğretmen, patron, hoca, müdür, büyükelçi, sultan" gibi unvan isimleri, benzetme kelimeleri aracılığıyla ifade edilen saygı sözleri, "sayın, saygıdeğer, zâtıâlîleri, muhterem, değerli” gibi saygı sözleri, "aziz, kardeş, meslektaş, sevgili" gibi resmi görüşmelerde kullanılan seslenme sözleri ve bu sözlere eklenen -clğlm ve -Im ekleriyle oluşturulmuş sözler, nezaket, saygı ve sevginin ifade edilmesinde büyük önem taşımaktadır (İmamova, 2010: 1-10). Bunların yanında seslenme sözleri olumsuz, küfür ve hakaret içeren, öfke ve şiddet duygularını yansıtan, aşağılama ve küçük görme amacıyla söylenen, dolayısıyla kibarlıktan uzak "kaba" sözler de olabilir.

\subsection{Seslenme Sözlerinde İmla ve Noktalama Kullanımı}

Tek başına kullanılan ve ünlem tümleci oluşturan seslenme ünlemlerinden sonra virgül; ilgili olduğu cümlenin sonunda da ünlem işareti konmalıdır, çünkü ünlem veya ünlem edatı öbeği içeren cümleler ünlem cümleleridir (Delice, 2012: 178). Bu işaretler dışında seslenme sözleri için özel işaretler yoktur. Seslenme edatları çok vurguludur ve vurgu başta bulunur (Ergin, 2002: 314). Konuşma dilinde vurgu ve tonlamayla diğer sözcük türlerinden ayırt edilebilirler ancak yazı dilinde bu ayrımı göstermek güçtür. Yapı bakımından özel bir durumu olan ünlemlerin yazııı̧ biçimleri konusunda belli bir kural ve ölçüt olmadığı için Türkçeyi ana dili olarak bilenler bağlamdan hareketle meseleyi fark etmektedirler ancak yeni öğrenmeye başlayanlar için durum oldukça karanlıktır (Gedizli, 2015: 132-133). Seslenmelerin, dolayısıyla ünlemlerin yazı dilinde de ayırt edilebilmeleri için belli ölçütlerin geliştirilmesi gerekmektedir. Ayrıca sözlüklerde uygun bağlamlardan örnek cümlelerle, işlevlere uygun sesletimlerin yer aldığı seslendirmelere de yer verilmeli (Çelebi ve Sancı Uzun, 2015: 315); dil kullanıcısı veya öğrenicisi için kolaylık sağlanmalıdır.

Seslenme sözleri genel sözlüklerde tanımlanırken bu sözlerin sahip oldukları özelliklere dikkat edilmesi ve özellikle yazı dilinden çok konuşma dilinde ortaya çıkan farklılıkların sözlüklere de doğru ve yeterli biçimde taşınması gerekmektedir.

\section{Türkçe Sözlük'te ve Misalli Büyük Türkçe Sözlük'te Seslenme Sözleri}

\subsection{Türkçe Sözlük'te Seslenme Sözleri}

Türkçe Sözlük’te (TS) "seslenme sözü” ya da "hitap sözü” olarak tanımlanan 79 sözlükbirim (madde başı, alt madde başı ve anlam) tespit edilmiştir:

a, abe, abla, ağabey, ahbap, alo, amca, ana, anam!, anam babam, aptal, aslanım!, âşık, ayol, babam!, babalık, bacı, balama, bakar mısınız?, baksana! (veya baksanıza!), bana bak!, be, bebek, beybaba, bey kardeş, birader, buyur! ${ }^{1}$, buyur! ${ }^{2}$, buyur! ${ }^{3}$, cana, cicim!, civanım, dadaş, dayı, dede, delikanlı, efendi, efendibaba, efendim, evlat, ey, gözüm! (veya gözümün nuru), güle güle, güzelim, hain, hayvan, hazret, hemşehrim!, hey, hiş, hişt, höst ${ }^{1}$, höst ${ }^{2}$, hu ${ }^{1}$, hu ${ }^{2}$, kardeş, kardeşlik, kı, kurban, lala, lebbeyk, majesteleri, manyak, minnoş, mirim, nine, oğul, oha, siz, şekerim!, teyze, ufaklık, ulan, üstat, ya, yavrum!, yenge, yeğen, zatıalileri, zatıaliniz. 
Fatih DOĞRU

\subsection{Misalli Büyük Türkçe Sözlük'te Seslenme Sözleri}

Misalli Büyük Türkçe Sözlük'te (MBTS) "seslenme sözü" ya da "hitap sözü" olarak tanımlanan 116 sözlükbirim (madde başı, alt madde başı ve anlam) tespit edilmiştir:

a, abe, abla, aga - aka, ağabey, ağa, ahbap - ahbab, ahbar, allah'ın kulu, amca, anam babam, anne, arkadaş, asâlet-meab, aslan, ayol, azizim, baba, babalık, bacı, bakar mısınız?, be, bebek, beşe, beyim, bey ağabey, beybaba, beyefendi, bezirgânbaşı, bir tanem, birâder $^{1}$, birâder ${ }^{2}$, büyük hanım, burama geldi (çıktı), buraya bak, cancă̆ızım, celil, cicim, ciğerim (ciğerimin köşesi), civanım, çakernevaz (-nuvaz), çaker-perver, çılgın, dayı, deli, delikanlı, devletli, dostum, efe, efendi, efendi baba, efendim, elmasım, erenler, eşek, evlat - evlad, ey, eyyuha, gözüm, gülüm, güzelim, hacı baba, hacı cavcav, hain, hanım, hanımefendi, hemşeri - hemşehri, hemşire, hey, hişt - hiş, hu, hu erenler, iki gözüm (iki gözümün) nuru (bebeği), ilahi, kadın, kardeş, kardeşlik, kız, koçum, kurban, küçük, küçük hanım, lala, lebbeyk, madam, matmazel, merhaba, meveddetlü ${ }^{1}$, meveddetlü ${ }^{2}$, mevlana, minnoş, mirim, mösyö, muhterem, müfettihu'l-ebvab, mürtecâ, nur-ı aynım, oğul, oha, paşa, riyasetpenahi, seyyidi, sittî, siz, sultanım, şaşkın, şekerim, teyze, ulan - ulen, usta, ümmet-i muhammed, üstat - üstad, yeğen, yenge, yoldaş, zat-ı ali, zat-ı humayun - zat-ı şahane.

\subsection{Türkçe Sözlük’te Yer Alıp Misalli Büyük Türkçe Sözlük’te Yer Almayan Seslenme Sözleri}

$T S$ 'de seslenme / hitap sözü olarak tanımlanıp MBTS'de bu şekliyle yer almayan "alo, ana, anam, aptal, aslanım!, âşık, babam, balama, baksana! (veya baksanıza!), bana bak!, bey kardeş, cana, dadaş, dede, güle güle, hayvan, hazret, majesteleri, manyak, nine, ufaklık, ya, yavrum!, zatıâlileri, zatıâliniz" sözlükbirimleri tespit edilmiştir.

\subsection{Misalli Büyük Türkçe Sözlük’te Yer Alıp Türkçe Sözlük'te Yer Almayan Seslenme Sözleri}

MBTS'de seslenme / hitap sözü olarak tanımlanıp TS' de bu şekliyle yer almayan “aga-aka, ağa, ahbar, allah'ın kulu, anne, arkadaş, asâlet-meab, aslan, azizim, baba, bacı, beşe, beyim, bey ağabey, beyefendi, bezirgânbaşı, bir tanem, büyük hanım, burama geldi (çıktı), buraya bak, cancağızım, celil, ciğerim (ciğerimin köşesi), çaker-nevaz (-nuvaz), çaker-perver, çılgın, deli, devletli, dostum, efe, elmasım, erenler, eşek, eyyuha, gülüm, hacı baba, hacı cavcav, hain, hanım, hanımefendi, hemşire, hu erenler, iki gözüm (iki gözümün) nuru (bebeği), ilahi, kadın, koçum, küçük, küçük hanım, madam, matmazel, merhaba, meveddetlü ${ }^{1}$, meveddetlü ${ }^{2}$, mevlana, mösyö, muhterem, müfettihu'lebvab, mürtecâ, paşa, riyaset-penahi, seyyidi, sittî, sultanım, şaşkın, usta, ümmet-i muhammed, yoldaş, zat-ı ali, zat-ı humayun - zat-ı şahane" sözlükbirimleri tespit edilmiştir. 


\subsection{Türkçe Ulusal Derlemde Seslenme Sözleri}

$T S^{\prime}$ de ve $M B T S$ 'de seslenme / hitap sözü olarak tanımlanan sözlükbirimler Türkçe Ulusal Derlem (http://www.tnc.org.tr)' de ${ }^{1}$ ünlem işaretli kullanılışlarıyla birlikte taranmış ve aşağıdaki sonuçlara ulaşılmıştır.

abe: 46/1 ${ }^{2}$, abla: 1689/82, ağabey: 1392/50 (abi: 3150/124), ahbap:144/6, alo: 510/65, amca: 2295/71, ana: 13804/11, anam: 727/40, anam babam: 15/3, aptal: 1121/31, aslanım!: 172/27, âşık: 3421/6, ayol: 393/39, babam!: 7448/8, babalık:323/17, balama: 1/0, bakar mısınız?: 3750/4, baksana!: 642/41, baksanıza!: $170 / 9$, bana bak!: $449 / 24$, be: $3444 / 518$, bebek: $2423 / 25$, bey kardeş: 0 , beybaba: $17 / 7$, birader: $232 / 16$, buyur!: $717 / 22$, cana: 0 , cicim!: $58 / 1$, civanım: $6 / 0$, dadaş: 43/0, dayı: 646/26, dede: $1751 / 48$, delikanlı: $1459 / 16$, efendi: $3769 / 51$, efendibaba: $1 / 0$ (efendi baba: 38/1), efendim: 4976/100, evlat: 943/29, gözüm! (veya gözümün nuru): 955/2 (26/0), güle güle: 396/22, güzelim: 1030/13, hain: 578/12, hayvan: 3742/18, hazret: 39/0, hemşehrim!: 26/0 (hemşerim: 132/12), hey: 1155/168, hiş: 14/0, hişt: 56/16, höst: 15/5, hu1: 293/14, hu2: 293/2, kardeş: 2072/54, kardeşlik: 478/2, kız: 15460/21, kurban: 2284/7, lala: 59/2, lebbeyk: 21/7, majesteleri: 16/0, manyak: 274/19, minnoş: 49/0, mirim: 20/3, nine: 464/6, oğul: 1036/61, oha: 56/6, siz: 14411/15, şekerim!: 354/19, teyze: 1461/28, ufaklık: 310/16, ulan: 1442/81 (lan: 1937/136), üstat: 272/5, yavrum!: 1094/83, yenge: $245 / 5$, yeğen: 90/2 (yeğenim: $164 / 4$ ), zatıalileri: 2/0, zatıaliniz: 11/0, aga-aka: 84/1, ağa: 1726/39, ahbar: 7/0, allah'ın kulu: 80/5, anne: 9635/90, arkadaş: 3721/55, asâlet-meab: 0, aslan: 1805/11, azizim: 107/7, baba: 7927/61, bacl: 267/9, beşe: 0, beyim: 312/25, bey ağabey: 0, beyefendi: 1359/58, bezirgânbaşı: 20/0, bir tanem: 116/3 (birtanem: 36/5, bi tanem: 5/0, bitanem: $17 / 1$ ), büyük hanım: $24 / 0$, burama geldi (çıkı): $8 / 1$ (0), buraya bak: 8/2, cancağızım: 19/1, celil: 0 (özel ad olarak: 225/8), ciğerim (ciğerimin köşesi): 73/3 (7/0), çâkernevaz (-nüvaz): 0, çâker-perver: 0, çılgın: 772/3, deli: 3180/28, devletli: 35/0, dostum: 1456/59, efe: 348/6, elmasım: 3/0, erenler: 116/4, eşek: 822/8, ey: 3158/23, eyyuha: 0, gülüm: $171 / 2$, hacı baba: 4/0, hacı cavcav: $11 / 4$, hain: 578/12, hanım: 9045/32, hanımefendi: 786/38, hemşire: 557/0, hu erenler: 0, iki gözüm (iki gözümün) nuru (bebeği): 2/0, ilahi: 1790/2, kadın: 27708/16, koçum: 111/11, küçük: 33385/0, küçük hanım: 112/7, madam: 386/6, matmazel: 128/1, merhaba: 1669/177, meveddetlü ${ }^{1}$ : 0, meveddetlü2: 0, mevlana: 696/0, mösyö: 372/8, muhterem:565/2, müfettihu'l-ebvab: 0, mürtecâ: 0, nur-ı aynım: 4/0, paşa: 6713/12, riyaset-penahi: 0, seyyidi: 10/2, sittî: 0, sultanım: 351/37, şaşkın: 2022/9, ulan - ulen: 1442/81 - 22/4, usta: 2794/42, ümmet-i muhammed: 56/1, yoldaş: 308/8, zat-ı ali: 14/0, zat-ı humayun - zat-ı şahane: 0 - 25/0.

\footnotetext{
${ }^{1}$ Derlemde henüz sözcük türü bilgisine göre tarama yapılamadığı için çıkan sonuçların içinde farklı sözcük türleri de bulunmaktadır. Bu bakımdan sonuçların tamamı seslenme sözlerini yansıtmadığı gibi fikir vermesi açısından (ünlem işaretiyle birlikte kullanılan sözleri de tarayarak) burada bu sonuçlara yer vermeyi uygun gördük.

${ }^{2}$ Türkçe Ulusal Derlem'de bulunan sözcük sayısı / ünlem işaretiyle birlikte kullanılan sözcük sayısı
} 
Fatih DOĞRU

\section{Değerlendirme}

\section{1. Ünlem İşaretinin Kullanımı}

TS'de seslenme / hitap sözü olarak tanımlanan bazı sözlükbirimlerin (anam!, aslanım!, babam!, baksana! (veya baksanıza!), bana bak!, buyur! cicim!, gözüm! şekerim!, yavrum!) sonunda ünlem işareti konulmuşken bir kısmında bu işaret yoktur. $M B T S^{\prime}$ de ise bu işaret hiçbir sözlükbirimin sonunda kullanılmamıştır.

\subsection{Sözlüğe Çok Anlamlılığın Yansıtılması}

1.a. aman: ünlem Arapça amān 1. ünlem Yardım istenildiğini anlatan bir söz. "Aman yakalayın." 2. Bir suçun bağışlanmasının istendiğini anlatan bir söz. "Aman, bir daha yapmam!" 3. (ama:n) Usanç ve öfke anlatan bir söz. "Aman bırak beni! Aman, bu laflardan da bıktık!" 4. Rica anlatan bir söz. "Aman, acele etmeli, vakit geçiyor." - S. F. Abasıyanık 5. Dikkat çekmek için kullanılan bir söz. "Aman, çocuğa iyi bakın!" 6. Çok beğenmeyi anlatan bir söz: Aman ne güzel şey! Bu anlamda kullanıldığında buna da edatı da getirilebilir "Aman da ne güzel şey!" 7. Şaşma anlatan bir söz. "Aman efendim, bana öyle şeyler söyledi ki donakaldım." (TS, 2011: 111).

b. hey: ünlem 1. ünlem Seslenmek veya ilgi ve dikkat çekmek için söylenen bir söz. "Hey, çocuklar! Gelin bakalım. Hey arkadaş! Ayağıma basıyorsun." 2. Sitem, yakınma, azar, beğenme vb. çeşitli duyguları anlatan cümlelerde kullanılan bir söz. "Hey talih! Böyle mi olacaktı? Hey akılsız çocuk! Ateşi ne diye ellersin? Hey Allah'ım! Bu ne güzellik." (TS, 2011: 1089).

hey: ünl. 1. Seslenmek ve bir kimsenin dikkatini çekmek için kullanılır: “Hey... buraya baksana!” 2. Azarlama, uyarı, üzüntü, sitem, tekdir, şüphe vb. duyguları anlatan cümlelerde anlama kuvvet verir: Sizin gibileri de temizledim hey imanım! (Sait Fâik). Hey yâ Rabbi! İnsanı deli eder bunlar... (Burhan Felek) (MBTS, kubbealtilugati.com).

TS'de seslenme / hitap sözü olarak tanımlanan 1.a'deki gibi bazı sözlükbirimler anlamlandırılııp sözlükbirimin sahip olduğu her bir ayrıntı farklı bir anlam ile ifade edilirken 1.b'nin TS ve MBTS'de 2. anlamlarındaki gibi bazı sözlükbirimlerde bu ayrıntılar "vb. çeşitli duyguları anlatan" ifadesiyle tek bir anlam altında birleştirilerek verilmiştir.

\subsection{Parçacı Yapıya iliş̧kin Verilen Bilgiler}

2.a.anam!: 1. sese verilen tona göre şaşma, beğenme, acı, üzüntü vb. duygular anlatan söz. "Anası mutfakta bir tabağa marul doğruyor." - Y. Atılgan 2. kadın erkek, büyük küçük herkese karşı kullanılan bir seslenme sözü (GTS, tdk.gov.tr). 
anam!: 1. sese verilen tona göre şaşma, beğenme, acı, üzüntü vb. duygular anlatan söz; 2. tkz. kadın erkek, büyük küçük herkese karşı kullanılan bir seslenme sözü: Dur, anam, saçını düzelteyim! (TS, 2011: 117).

b. babam!: teklifsiz konuşmada 1. sese verilen tona göre şaşma, beğenme, acı, üzüntü vb. duygular anlatan söz. 2. kadın erkek, büyük küçük herkese karşı kullanılan bir seslenme sözü. "Türk babanın ve Türk ananın çocuğu Türk'tür." - Anayasa (GTS, tdk.gov.tr).

babam!: tkz. 1. sese verilen tona göre şaşma, beğenme, acı, üzüntü vb. duygular anlatan söz; 2. kadın erkek, büyük küçük herkese karşı kullanılan bir seslenme sözü. Sen bildiğini söyle babam, alt yanını ben getiririm! (TS, 2011: 219).

Güncel Türkçe Sözlük (GTS)'de seslenme / hitap sözü olarak tanımlanan 2.b'deki gibi bazı sözlükbirimlerde "teklifsiz konuşmada" ibaresi verilirken 2.a'daki gibi aynı kategorideki bazı sözlükbirimlerde bu ibareye yer verilmemiştir. Ayrıca bu sözlükbirimlerde ünlem işareti konulmuş olmasına rağmen sözcük türü bilgisine (ünlem) yer verilmemiştir. TS'de ise 2.a'nın 2. anlamından önce verilen "tkz." ibaresi 2.b’nin 1. anlamında verilmiş; bu durum aynı kategorideki, hatta birebir aynı şekilde tanımlanmış bu sözlükbirimlerde karmaşık bir duruma yol açmıştır. Ayrıca 2.a ve 2.b'deki sözlükbirimlerin birebir aynı olan anlamlarının, birbirlerinden ayrılan noktaları gösteren anlambirimcikler yoluyla yeniden düzenlenmesi gerekmektedir.

\subsection{Verilen Örneklerin Uygunluğu}

GTS'de seslenme / hitap sözü olarak tanımlanan sözlükbirimlerin anlamları altında verilen örneklerde 2.a'nın 1. anlamı ve 2.b'nin 2. anlamında olduğu gibi bazı örnekler verilen anlamla ilgisizdir. Bu durum TS'deki örneklerde görülmemektedir. GTS'de alt madde başı durumundaki sözlükbirimler tarandığında her bir farklı sözlükbirimin altında aynı örnek cümlenin yer aldığı görülmüştür. GTS ve TS'de pek çok anlamda örnek verilmemiş olması bir eksiklik olarak göze çarpmaktadır.

\subsection{Alt Madde Başı Düzenine ilişkin Tasnif}

GTS'de 2.a ve 2.b örneklerinde olduğu gibi sözlükbirimler alt madde başı olarak "Atasözü, deyim ve birleşik fiiller" başlı̆ı altında gösterilmektedir. Halbuki bu başlık bu sözlükbirimler için uygun bir sınıflama olmamıştır. Bu gibi sözlükbirimlerin özelliklerini de kapsayacak daha kapsamlı ve doğru bir başlık altında verilmeleri daha uygun olacaktır.

\subsection{Vurgunun Gösterilişi}

3.a oha: ünlem (o:ha, o:ha:) 1. ünlem Büyükbaş hayvanları durdurmak için kullanılan bir seslenme sözü. 2. Kaba ve yakışıksız davranışta bulunan kişilere karşı kullanılan söz (TS, 2011: 1790). 


\section{Fatih DOĞRU}

a: ünlem (a:) 1. ünlem Şaşma, hatırlama, sevinme, acıma, üzülme, kızma vb. duyguların anlatımına güç kazandıran söz. "A, ne güzel!" "A, sen burada mıydın?" (TS, 2011: 1).

b. höst: ünlem 1. ünlem At, katır, sığır vb. hayvanları, özellikle öküzü durdurmak için kullanılan bir seslenme sözü. "Höst, höst diye bağırdı. At oralı olmadı." - A. Sayar 2. Bir kimseyi uyarmak için kullanılan bir seslenme sözü (TS, 2011: 1113).

c. oha: ünl. 1. Büyükbaş hayvanları durdurmak için kullanılan seslenme sözü: Çataltepe'nin kıvrıntısında görmediğimiz bir kadın sesi "oha oha, hele hele hele" diye haykırdı (Rûşen E. Ünaydın). 2. kaba. Biçimsiz ve olmayacak bir davranışta bulunan kimselere karşı söylenir (MBTS, kubbealtilugati.com).

TS'de seslenme / hitap sözü olarak tanımlanan 3.a'daki gibi bazı sözlükbirimlerde parantez içinde vurgu ile ilgili bilgilere yer verilirken 3.b ve MBTS'de 3.c'deki gibi bazı sözlükbirimlerde bu bilgilere yer verilmemiştir.

\subsection{Sözcük Türü Bilgisi}

4.a.teyze isim (te'yze) 1. isim Annenin kız kardeşi, ana yarısı. "Teyzem de çok gecikiyor, uyuyakalmışım yeniden." - A. Ağaoğlu 2. ünlem Anne yaşıtı kadınlara söylenen bir seslenme sözü (TS, 2011: 2343).

güzelim ünlem 1. ünlem çok sevilen kimseye sevecenlikle yaklaşıldığında kullanılan bir söz. 2. değer verilen, sevilen "Son yıllarda rant uğruna kurban edilen güzelim yerler arasına hem o çarşı hem balıkhane girdi." - A. Kutlu (GTS, tdk.gov.tr).

b. siz zamir1. zamir Çokluk ikinci kişi zamiri. 2. Bir kişiye saygı ve incelik belirtisi olarak kullanılan bir seslenme sözü (TS, 2011: 2126).

balama isim, tiyatro 1 . isim, tiyatro Orta oyununda Rum tipi. 2. Karagöz, matiz ve külhanbeyi tipleri tarafından yabancı ülkelerin tiplerine seslenirken kullanılan söz (TS, 2011: 242).

c. teyze: i. (Türk. taḡāy > tay "dayı" ve eze "büyük kız kardeş" ile tay eze+si > *tayaza > *teyeze > teyze) 1. Bir kimseye göre annesinin kız kardeşi. 2. Annenin kız kardeşi yerine konan kimse. 3. Anne yaşındaki kadınlar için kullanılan hitap sözü (MBTS, kubbealtilugati.com).

sittî: i. (Ar. seyyideti "benim hanımım"dan sitti) 1. Hanım, hâtun, hanımefendi. 2. Eskiden hanımlar için kullanılan bir hitap sözü (MBTS, kubbealtilugati.com).

d. güzelim: sıf. (İyelik ekinin kalıplaşmasıyle güzel+i+m) 1. Pek güzel olan, beğenilip hoşa gitmekte olan, güzel olup sevilen: "Güzelim kıza yazık oldu." İşte kimse şu güzelim hayvana fiyatını vermemişti (Ömer 
Seyfeddin). Güzelim bahar rüzgârında ter kokuları (Orhan V. Kanık). 2. ünl. Beğenilen, sevilen kimselere hitap sözü olarak kullanılır, şekerim: “Güzelim, biraz bakar mısın?" (MBTS, kubbealtilugati.com).

dostum: ünl. (Iyelik ekinin kalıplaşmasıyle) Saygı ve yakınlık belirten hitap sözü: Öyle kaba sanatlar bir işe yaramaz dostum! (Ahmed Midhat Efendi). Nasıl söyleyeyim a dostum! (Ahmed Midhat Efendi). Geliniz aziz dostum, geliniz! (Refik H. Karay) (MBTS, kubbealtilugati.com).

mîrim: ünl. (İyelik ekinin kalıplaşmasıyle) "Beyim, aziz dostum, arkadaşım, efendim" anlamında bir hitap sözü: Tez ol mîrim, tez ol! (Safiye Erol) (MBTS, kubbealtilugati.com).

seyyidî: ünl. (Ar. mütekellim yā'sı -i ile) "Efendim" anlamında hitap sözü, halk ağzında seydî şeklini almıştır: "Yâ seyyidî: Ey benim efendim!" (MBTS, kubbealtilugati.com).

şekerim: ünl. (İyelik ekinin kalıplaşmasıyle) Daha çok hanımlar arasında kullanılan teklifsiz bir hitap sözü, tatlım, güzelim: Ayağını denk al şekerim (Orhan V. Kanık) (MBTS, kubbealtilugati.com).

TS'de 4.a'dazi "teyze" sözlükbiriminin seslenme sözü olarak tanımlanan 2. anlamında "ünlem" sözcük türü bilgisi verilmişken 4.b'de seslenme sözü olarak tanımlanan 2. anlamlarda bu bilgiye yer verilmemiştir. $T S^{\prime}$ de alt madde başı olan 4.a'daki "güzelim" sözlükbirimi dışındaki "anam!, anam babam, aslanım!, babam!, bakar mısınız?, baksana! (veya baksanıza!), bana bak!, buyur!, cicim!, gözüm! (gözümün nuru), hemşehrim!, majesteleri, mirim, şekerim, yavrum!" sözlükbirimlerinin hiçbirinde sözcük türü bilgisinin belirtilmediği tespit edilmiştir. $M B T S^{\prime}$ de 4.c'de gibi hitap sözü olarak tanımlanan "tezye" sözlükbiriminin 3., "sittı̂" sözlükbiriminin 2. anlamından önce sözcük türü bilgisine yer verilmemiştir. MBTS'de alt madde başı olan 4.d'deki "güzelim" sözlükbirimin 2. anlamında; "dostum", "mîrim”, "seyyidî” ve "şekerim" sözlükbiriminde sözcük türü bilgisine yer verilirken alt madde başı olan diğer seslenme sözlerinde (anam (anam babam), Allah'ın kulu, asâletmeab, azizim, bakar mısınız?, beyim, bir tanem, burama geldi (çıktı), buraya bak, cancağııı, cicim, ciğerim, civanım, elmasım, erenler, gözüm, hu erenler, iki gözüm (iki gözümün) nuru (bebeği), koçum, meveddetlü, müfettihu'l-ebvab, nur-ı aynım, riyaset-penahi, sultanım, ümmet-i muhammed, zat-ı ali, zat-ı humayun - zat-ı şahane) bu bilginin yer almadı̆̆ı tespit edilmiştir.

\subsection{Uzunluğun Gösterilişi}

5.a.alo ünlem (a'lo, I ince okunur) Fransızca allô 1. ünlem Telefon konuşmasına başlarken kullanılan bir seslenme sözü. 2. (alooo) Kendisine bakmasını veya kendisiyle ilgilenmesini istediği kişiye karşı söylenen seslenme sözü (TS, 2011: 104).

TS'de 5.a'nın 2. anlamında seslenme sözündeki uzunluk parantez içinde aynı harf birkaç defa yazılarak gösterilmiştir. Diğer örneklerde böyle bir düzenlemeye rastlanmamıştır. 
Fatih DOĞRU

\subsection{Anlam Ayırt Edici Anlambirimciklerin Kullanımı}

6.a.bana bak! teklifsiz konuşmada "beni dinle" anlamında kullanılan bir seslenme ve gözdağı sözü: "Bana bak, karışmam sonra!" (TS, 2011: 249).

b. baksana! (veya baksanıza!) teklifsiz konuşmada 1. bir seslenme sözü. 2. dikkat çekme sözü "Akşam oluyor, baksana hava karardı." (TS, 2011: 240).

TS'de 6.a'da seslenme sözü “'beni dinle' anlamında, gözdağı sözü” gibi ayırt edici anlambirimciklerle birlikte tanımlanırken $6 . b^{\prime}$ de bu türden anlambirimciklere yer verilmeyerek yalnızca "bir seslenme sözü" şeklinde tanımlanmıştır. Anlamın daha açık ve belirleyici olması için tanımlarda ayırt edici anlambirimciklere yer verilmesi gerekir.

\subsection{Tümce Yapısındaki Sözlükbirimlerin Sözlüğe Alınma Ölçütleri}

TS'de "bakar mısınız?, baksana! (veya baksanıza!), bana bak!, buyur!"; MBTS'de "bakar mısInız?, burama geldi (çıkı), buraya bak" örneklerinde çekimli eylemlerin seslenme sözü olarak tanımlandıkları görülmektedir. Kimi zaman soru yoluyla, kimi zaman emir kipiyle, kimi zaman da kalıplaşmış farklı cümle tipleriyle seslenmeler olabilmektedir. Bu durumda sözlüğe bu tipteki seslenme sözlerinden hangilerinin alınıp hangilerinin alınmayacağının ölçütü belirlenmeli, sözlükbirimler bu ölçüte göre sözlüğe dâhil edilmelidir.

\subsection{Teklik Kişi İyelik Ekli Sözlükbirimler}

TS'de “anam!, anam babam, aslanım!, babam!, cicim!, gözüm! (gözümün nuru), güzelim, mirim, şekerim!, yavrum! ve MBTS'de "anam babam, azizim, beyim, bir tanem, cancağızım, cicim, ciğerim (ciğerimin köşesi), civanım, dostum, elmasım, gözüm, gülüm, güzelim, koçum, mirim, nur-ı aynım, sultanım, şekerim" sözlükbirimleri gibi 1. teklik kişi iyelik eki almış seslenme sözleri dikkati çekmektedir. TS'de ve MBTS'de Türkçe Ulusal Derlem'den yapılan kontrol sonucu kullanım sıklıkları oldukça yüksek olduğunu tespit ettiğimiz "annem(6772/13), aşkım (282/3), bebeğim (178/3), hayatım (1105/15), kardeşim (2226/94), küçüğüm (112/6), meleğim (46/2), sevgilim (901/39)" gibi seslenme sözlerine de seslenme sözü olarak yer verilmesi beklenmektedir.

\subsection{Seslenme Sözü Olarak Tanımlanmayan Sözlükbirimler}

$T S^{\prime}$ de ve MBTS'de seslenme / hitap sözü olmasına rağmen bu şekilde tanımlanmayan sözlükbirimler de vardır; "bir tanem, canım, damat, dengesiz, emmi, emmi kızı, emmi oğlu, enişte, gelin, hala, hala kızı, hala oğlu, haysiyetsiz, komşu, kuzum, namussuz, salak, sevdiceğim, sevdiğim, şerefsiz" gibi seslenme / hitap sözlerinin tanımlarında da seslenme sözü oldukları belirtilmelidir.

\subsection{Kullanım Sıklığı Düşük Olan Sözlükbirimler}

TS'de seslenme / hitap sözü olarak tanımlanan balama: 1/0, bey kardeş: 0, cana: 0 , zatıâlileri: 2/0 ve $M B T S^{\prime}$ deki ahbar: 7/0, asâlet-meab: 0 , beşe: 0 , bey ağabey: 0 , burama geldi (çıtı): $8 / 1$ (0), buraya bak: 8/2, celil: 0 civanım: 6/0, çâker-nevaz (-nüvaz): 0 , çâker-perver: 0 , elmasım: 3/0, 
eyyuha: 0 , hacı baba: $4 / 0$, , hu erenler: 0 , iki gözüm (iki gözümün) nuru (bebeği): $2 / 0$, meveddetlü: 0 , müfettihu'l-ebvab: 0 , mürtecâ: 0 , nur-ı aynım: 4/0, riyaset-penahi: 0 , seyyidi: $10 / 2$, sittî: 0 , zat-ı hümayun: 0 sözlükbirimlerinin kullanım sıklıklarının düştüğü, hatta bazılarının hiç kullanılmadığı tespit edilmiştir. Böyle sözlükbirimlerin belirli aralıklarla derlem kontrolü yapılmalı ve kullanımda olmadığı tespit edilenlere sözlüklerde yer verilmemeli; eğer tarih içinde kullanımdan düşmüşlerse "eskimiş" etiketi eklenmelidir (TS'de "cana" ve "lala", MBTS'de "beşe", "celii", "çâker-nevaz (nüvaz)", "çâker-perver", "devletli", "meveddetlü"1", "meveddetlü"”, "nur-ı aynım" ve "sittî" seslenme sözlerine bu etiket eklenmiştir). Ayrıca yine ulusal derlemde taradığımız ve kullanım sıkıkları $T S^{\prime}$ de ve $M B T S^{\prime}$ 'de yer verilen bu sözcüklerden daha yüksek olan "cicianne (26/1), hanım anne (hanımanne) (7), hanım abla (hanımabla) (28/5), hanım teyze (40), sizler (1065/9) gibi seslenme sözlerine sözlüklerde yer verilmesi uygun olacaktır.

\section{Sonuç}

Genel Türkçe sözlüklerde (TS'de ve MBTS'de) seslenme / hitap sözü olarak tanımlanan sözlerle ilgili tespit ve önerilerimiz şunlardır:

1. Genel Türkçe sözlüklerde seslenme sözleri tanımlanırken bir takım eksiklikler ve ikilikler tespit edilmiştir. Yapılan tanımlar seslenme sözlerinin niteliği ve türü göz önünde bulundurularak belli ölçütlere göre yapılmalıdır.

2. Hangi seslenme sözlerinin sözlüğe alınıp hangilerinin alınmaması gerektiği hususunda mutlaka derlem kontrolü yapılmalı ve kullanım sıklığı dikkate alınarak buna karar verilmelidir. Kullanımda olmayanlar sözlüğe alınmamalı, eskimiş ve kullanım sıklğı düşmüş sözler ise eskimiş etiketiyle belirtilmelidir.

3. Tanımlar yapilırken kullanılan anlambirimcikler standart olmal, aynı kategorideki tanımlamalar için farklı farklı anlambirimciklerin kullanılmasından kaçınılmalıdır. Ancak bu sözleri birbirinden ayıran temel farklılıları gösteren anlambirimciklere tanımlarda mutlaka yer verilmelidir.

4. Sözlükbirimlere ait parçacıl yapılara eksiksiz yer verilmeli; sözcük türü bilgisi ve vurgu, tonlama gibi özellikler mutlaka sözlükbirimlerin tamamında gösterilmelidir.

5. Ünlem işareti kullanımı ile ilgili ölçüt belirlenmeli, -varsa- ölçütün ne olduğu sözlükte tarif edilmeli; ya ünlem türündeki bütün sözlükbirimlerde bu işaret bulundurulmalı ya da hiçbirinde bulundurulmayarak bu husustaki karışıklık giderilmelidir.

6. Seslenme sözünün -varsa- yüklendiği her farklı duygu ve yönelimle ilgili anlam yeni bir anlam olarak verilmeli, çokanlamlı yapı sözlüğe yansıtılmalıdır.

7. Seslenme sözlerinin tanımlarındaki her bir anlamdan sonra o anlamla ilgili örneklere mutlaka yer verilmelidir. 
Fatih DOĞRU

\section{Kaynaklar}

Akalın, Ş. H. (2011). "Türkiye Türkçesinde Ünlem (Terim ve Tasnif, Tasnif, Ünlem Olan Kelimeler, Söz Dizimi ile İlgili Sorunlar)", Türk Gramerinin Sorunları I-Il Bildiriler, Türk Dil Kurumu Yayınları, s.588-603, Ankara.

Aksan, Y. et al. (2012). Construction of the Turkish National Corpus (TNC). In Proceedings of the Eight International Conference on Language Resources and Evaluation (LREC 2012). Istanbul. Turkiye. http://www.Irecconf.org/proceedings/Irec2012/papers.html

Akşehirli, S. (2004). Temel Anlambilim (Semantik) Kavramları Üzerine Bir Inceleme, Ege Üniversitesi Sosyal Bilimler Enstitüsü, Yayımlanmamış Yüksek Lisans Tezi, İzmir.

Alyılmaz, C. (1994). Orhun Yazıtlarının Söz Dizimi, Atatürk Üniversitesi Sosyal Bilimler Enstitüsü Yayımlanmamış Doktora Tezi, Erzurum.

Alyılmaz, C. (2011). "Ünlemlerin Seslenmeleri Kuvvetlendirici İşlevleri”, Türk Gramerinin Sorunları I-II Bildiriler, Türk Dil Kurumu Yayınları, s.646-652, Ankara.

Alyılmaz, S. (2015a). "Türkçenin Söz Diziminde Seslenmeler ve Seslenme Öbekleri”, A.Ü. Türkiyat Araştırmaları Enstitüsü Dergisi (TAED), S.54, s.31-50, Erzurum.

Alyılmaz, S. (2015b). “Dede Korkut Kitabındaki Bir Sözcükten (Boy) Hareketle "Bo, Bu, Abo, Abu..." Seslenme Ögelerinin Yapısı", Uluslararası Türkçe Edebiyat Kültür Eğitim Dergisi, S: 4/4, s. 1413-1424.

Atabay, N.; Özel, S. ve Kutluk, ì. (2003). Sözcük Türleri, Papatya Yayıncılık, İstanbul.

Ayverdi, í. (2010). Misalli Büyük Türkçe Sözlük (MBTS), Kubbealtı Yayınları, İstanbul.

Banguoğlu, T. (2007). Türkçenin Grameri, Türk Dil Kurumu Yayınları, Ankara.

Bulut, S. (2012). Anadolu Ağızlarında Kalıp Sözler ve Kullanım Özellikleri, Ordu Üniversitesi Sosyal Bilimler Enstitüsü Yayımlanmamış Yüksek Lisans Tezi, Ordu.

Çelebi, S. ve Sancı Uzun, D. (2015). "TDK Güncel Türkçe Sözlük ile TDK Sesli Türkçe Sözlük'ün Ünlemlerin İşlevleri Bakımından Karşılaştırılması”, International Journal of Language Academy, C.3/1, s.303-318.

Delice, H. İ. (2007). Türkçe Sözdizimi, Kitabevi Yayınları, İstanbul.

Delice, H. İ. (2012). Sözcük Türleri, Asitan Kitap, Sivas.

Demirbaş, M. (2017). "Türkiye Türkçesi Ağızlarında Seslenme Sözleri”, Uluslararası Türkçe Edebiyat Kültür Eğitim Dergisi, S: 6/4, s. 2154-2181.

Demirci, K. (2015). Kelime Bilgisi El Kitabı, Anı Yayıncılık, Ankara. 
Dinar, T. (2014). "Türkiye Türkçesi ve Türkmen Türkçesinde Cümle Dışı Unsur", SDÜ Fen Edebiyat Fakültesi Sosyal Bilimler Dergisi, S.33, s.69-86.

Dizdaroğlu, H. (1976). Tümce Bilgisi, Türk Dil Kurumu Yayınları, Ankara.

Doğru, F. (2014). "Türkçe Buyrum Tümcelerinde Kibarlık/Kabalık", VI. Uluslararası Dünya Dili Türkçe Sempozyumu Bildirileri (Editörler: Hatice Şahin ve Ibrahim Karahancı), C.1, Bursa.

Emre, A. C. (1945). Türk Dilbilgisi, Türk Dil Kurumu Yayınları, İstanbul.

Ergin, M. (2002). Üniversiteler için Türk Dili, Bayrak Yayınları, İstanbul.

Gedizli, M. (2015). "Türkçede Ünlemler ve Temel İ̧̧levi”, Uluslararası Sosyal Araştırmalar Dergisi, C.8, S.36, s.126-134.

Gencan, T. N. (2007). Dilbilgisi, Tek Ağaç Yayıncılık, Ankara.

Gencay, N. (2012). Kuzey Kıbrıs Türk Ağızlarında Kalıp Sözler, Doğu Akdeniz Üniversitesi Lisansüstü Eğitim, Öğretim ve Araştırma Enstitüsü Yayımlanmamış Yüksek Lisans Tezi, Gazimağusa, Kuzey Kıbrıs.

Hacıeminoğlu, N. (1984). Türk Dilinde Edatlar(3. Baskı), Milli Eğitim Basımevi, İstanbul.

Hatipoğlu, V. (1972). Türkçenin Sözdizimi, Türk Dil Kurumu Yayınları, Ankara.

İmamova, H. (2010). "Türkiye Türkçesi ile Özbek Türkçesinde Nezaket Anlamı Taşıyan Seslenmeler", A.Ü. Türkiyat Araştırmaları Enstitüsü Dergisi (TAED), S.42, s.1-10, Erzurum.

Karaağaç, G. (2009). "Edat Üzerine Düşünceler", Gazi Türkiyat Türkoloji Araştırmaları Dergisi, S. 5, s. 157-169.

Karaağaç, G. (2012). Türkçenin Dil Bilgisi, Akçağ Yayınları, Ankara.

Karaağaç, G. (2013). Dil Bilimi Terimleri Sözlüğü, Türk Dil Kurumu Yayınları, Ankara.

Karahan, L. (1995). Türkçede Söz Dizimi (3. Baskı), Akçağ Yayınları, Ankara.

Kononov, A. N. (1956). Çağdaş Türk Edebi Dilinin Grameri (Tercüme: Sabit Saylı), Moskova-Leningrad.

Korkmaz, Z. (2010). Gramer Terimleri Sözlüğü (4. baskı), Türk Dil Kurumu Yayınları, Ankara.

Korkmaz, Z. (2011). Türkçede Eklerin Kullanılış Şekilleri ve Ek Kalıplaşması Olayları (5.baskı), Türk Dil Kurumu Yayınları, Ankara.

Mehmedoğlu, A. (2002). "Türkiye Türkçesinde Bazı Gramer Terim ve Anlayışları Üzerine”, TDAY-Belleten, C.II, Ankara. 
Fatih DOĞRU

Özkan, M. ve Sevinçli, V. (2013). Türkiye Türkçesi Söz Dizimi (5. Baskı), Akademik Kitaplar, İstanbul.

Özmen, M. (1995). "Cümlenin Altıncı Ögesi ve Bir Terim Önerisi”, Türk Dili Dergisi, Türk Dil Kurumu Yayınları, S.519, s.224-227.

Özmen, M. (2013). Türkçenin Sözdizimi, Karahan Kitabevi, Adana.

Şen, S. (2008). "Dede Korkut Kitabı'nda Kadına Yönelik Hitaplar”, Turkish Studies International Periodical For the Languages, Literature and History of Turkish or Turkic, S.3/2, s.627-641.

Türkçe Sözlük (TS) (2011). (haz.: Şükrü Halûk Akalın ve diğerleri) (11. Baskı), Türk Dil Kurumu Yayınları, Ankara.

Üstüner, A. (1998). "Cümlenin Ögeleri Konusundaki Karışıklıklar”, Türk Dili Dergisi, Türk Dil Kurumu Yayınları, S.553, s.18-30.

Yoldaşev, A. A. (2012). "Türk Dillerinde Sesleniş Sözcükleri (Çev.: Bahar Güneş)”, Türkiyat Araştırmaları Enstitüsü Dergisi, S.48, s.441-446.

Zülfikar, H. (2011). "Ünlemler ve Ses Yansımalı Kelimeler”, Türk Gramerinin Sorunları I-II Bildiriler, Türk Dil Kurumu Yayınları, s.604-607, Ankara.

Elektronik Kaynaklar

Misalli Büyük Türkçe Sözlük (MBTS). http://www.kubbealtilugati.com/ (Erişim tarihi: 12.10.2015).

Güncel Türkçe Sözlük (GTS). http://tdk.gov.tr/ (Erişim tarihi: 12.10.2015).

Türkçe Ulusal Derlem. http://www.tnc.org.tr/ (Erişim tarihi: 13.10.2015). 